Chirurgia (2020) 115: 526-529

No. $4, \quad$ July - August

Copyright@ Celsius

http://dx.doi.org/10.21614/chirurgia.115.4.526

\title{
Obstructive Jaundice Secondary to Clip Migration in the Common Bile Duct 9 Years after Laparoscopic Cholecystectomy
}

\author{
Mihai Angelescu, Octavian Enciu*, Victor Florescu, Adrian Miron \\ Department of Surgery, Elias University Emergency Hospital, Bucharest, Romania
}

${ }^{*}$ Corresponding author:

Octavian Enciu, MD

Elias University Emergency Hospital Department of Surgery

17 Mărăsti Blvd, Bucharest, Romania

E-mail: esoctavian@gmail.com

\section{Rezumat \\ Icter mecanic secundar migrării unui clip chirurgical în calea biliară principală la 9 ani după colecistectomie laproscopică}

Migrarea unui clip chirurgical în calea biliară principală cu formare consecutivă de calcul reprezintă o complicație rară după colecistectomie laparoscopică, mai puțin de 100 de cazuri fiind raportate până în prezent. Prezentăm cazul unei femei de 55 de ani cu icter obstructiv prin calcul format în jurul unui clip migrat la 9 ani după colecistectomie laparoscopică. Ecografia abdominală a diagnosticat dilatarea căii biliare principale şi a căilor biliare intrahepatice iar computer tomografia a indicat prezența unui clip metalic în partea distală a coledocului. Tratamentul prin colangio-pancreatografie endoscopică retrogradă (ERCP) a fost eficient iar clipul a fost recuperat folosind sonda Dormia. Mecanismul exact prin care se produce migrarea clipului nu este complet înțeles dar poate fi explicat de inflamația locală şi clipare ineficientă. Deşi este un eveniment rar, migrarea de clip nu ar trebui exclusă în diagnosticul diferențial al pacienților cu icter sau colangită după colecistectomie laparoscopică. Tratamentul minim invaziv prin ERCP este prima optiune de tratament pentru complicatii produse de clipuri migrate dar explorarea chirurgicală a căii biliare poate fi necesară.

Cuvinte cheie: migrare de clip, icter obstuctiv, ERCP, colecistectomie laparoscopică 


\section{Abstract}

Surgical clip migration in the common bile duct with consecutive stone formation is a rare occurrence after laparoscopic cholecystectomy, less than 100 cases being reported so far. We report a case of a 55-year-old woman with obstructive jaundice due to bile duct stone formed around a migrated surgical clip 9 years after laparoscopic cholecystectomy. The patient presented with pain in the upper abdomen and jaundice. Abdominal ultrasound diagnosed dilation of the common bile duct and intrahepatic bile ducts. The diagnosis was confirmed by computed tomography which revealed a metal clip in the distal part of the common bile duct. The patient was managed successfully by endoscopic retrograde cholangiopancreatography (ERCP) and the surgical clip was retrieved using the Dormia basket. The exact mechanism of clip migration is not fully understood but may be explained by local inflammation and ineffective clipping. Although a rare occurrence, clip migration should not be excluded when considering the differential diagnosis of patients presenting with obstructive jaundice or cholangitis after laparoscopic cholecystectomy. Minimally invasive management by ERCP is the procedure of choice for migrated clips related complications but surgical common bile duct exploration may be necessary.

Key words: foreign body, clip migration, obstructive jaundice, laparoscopic cholecystectomy

\section{Case Report}

The case report concerns a 55-year-old caucasian woman who presented with a 5-day history of upper abdominal pain and jaundice. Nine years before she underwent laparoscopic cholecystectomy and transcystic biliary drainage followed by ERCP for biliary pancreatitis. The discharge documents noted the patient underwent cholecystectomy for chronic cholecystitis (biliary microlithiasis) during the same admission, after the pancreatitis resolved; after intraoperative cholangiography, a 6 Fr transcystic catheter was secured in place with 2 surgical clips to aid the ERCP in a rendez-vous manner. The first attempt to perform ERCP failed (failed cannulation) but succeeded 4 days after with removal of small bile duct stones. The patient had an uneventful course and was discharged with the trancystic catheter in place and returned after 14 days to have it removed after the control cholangiography.

The physical examination reveled mild pain in the right upper quadrant and icteric sclera. Laboratory blood tests results included normal leukocyte count and $\mathrm{C}$ reactive protein, total bilirubin of $6.7 \mathrm{mg} / \mathrm{dl}$ with direct bilirubin of $5.2 \mathrm{mg} / \mathrm{dl}$, gamma glutamyl transpeptidase of $513 \mathrm{U} / \mathrm{L}$, alkaline phosphatase of $215 \mathrm{U} / \mathrm{L}$ and elevated transaminases. Abdominal ultrasound described dilated extra hepatic biliary ducts. An abdominal CT scan was obtained that described a $13 \mathrm{~mm}$ common bile duct containing an opaque line in the distal segment - presumed to be a surgical clip (Fig. 1).

ERCP was then performed: the previous sphincterotomy was efficient and cannulation was undemanding due to the previous apparently efficient sphincterotomy; contrast examination exposed the brown common bile duct stone (Fig. 2) concentrated around a surgical clip used during laparoscopic cholecystectomy; the calculus was retrieved using the Dormia basket. The post procedural course was uneventful and the patient was discharged after 3 days without pain, normal bilirubin and improved liver function tests.

\section{Discussion}

Migration of surgical clips after laparoscopic cholecystectomy has been reported since 1992 


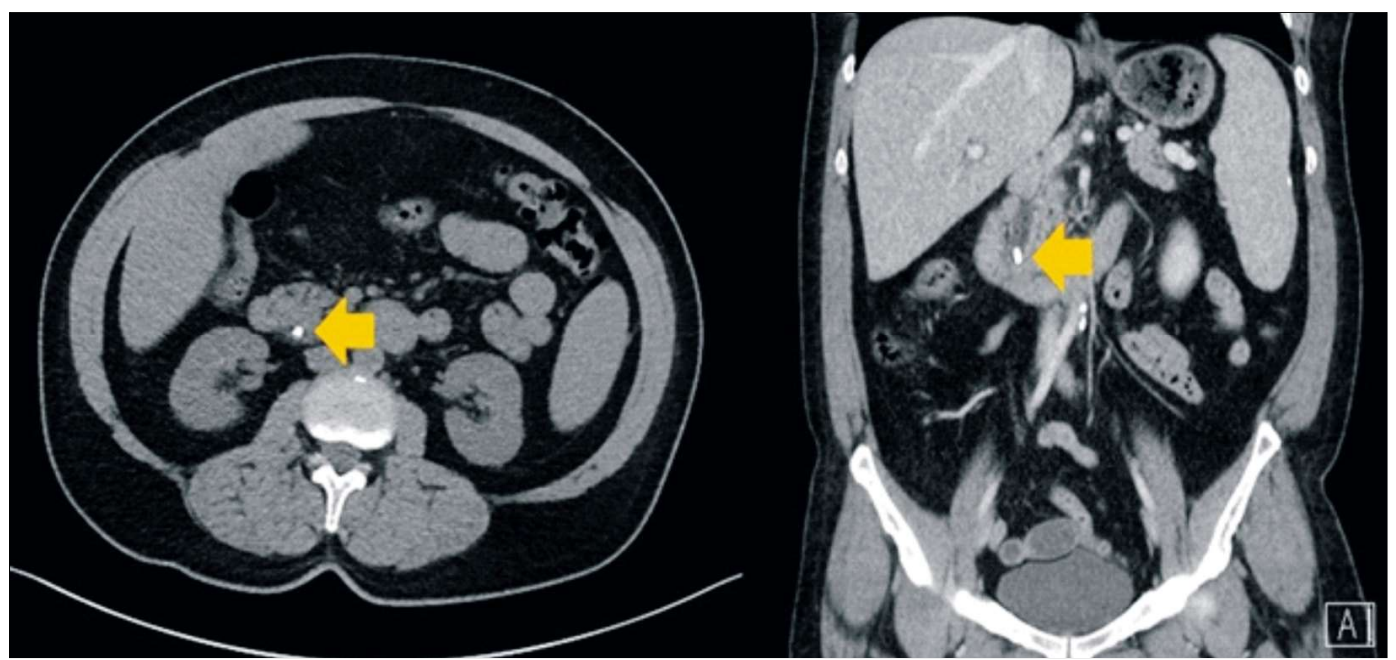

Figure 1. CT scan - Dilated common bile duct containing opaque line in the distal segment (surgical clip)

(1). To our knowledge, less than 100 cases have been reported, even though the number of laparoscopic interventions have increased worldwide (2).

Kitamura et al. presumed early on that the structures surrounding the clipped cystic duct pressed against it and led to its inversion into the lumen of the common bile duct (3) but more likely, the migration is determined by ineffective clipping that leads to leakage and chronic inflammation (2). In a similar manner, local inflammation may lead to erosion of the common bile duct wall and migration of clips;

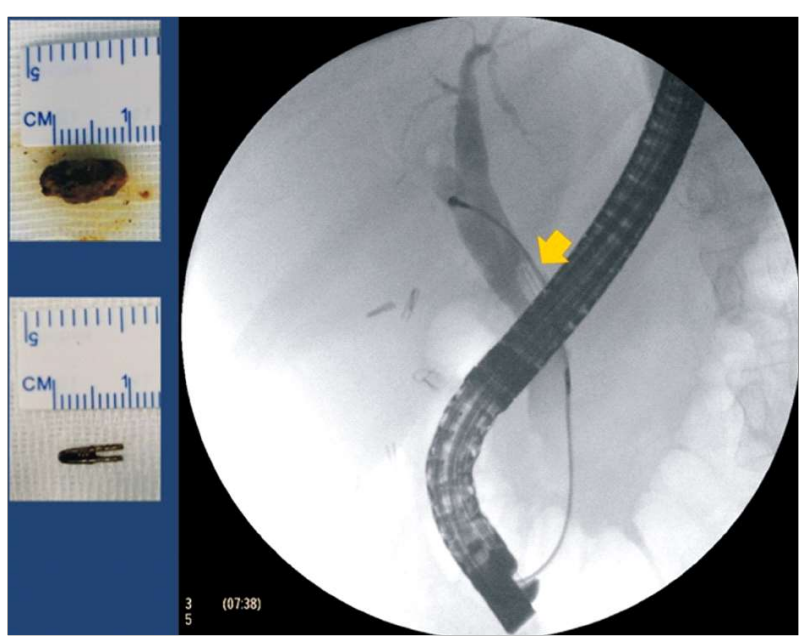

Figure 2. ERCP - Calculus formed around a surgical clip; the calculus was retrieved using the Dormia basket; detail of the structure on the left side the risk is higher if clips placed on the cystic artery or cystic duct are adjacent to the common bile duct wall (4). Deans et al. suggested that cystic stump necrosis due to ischemia may facilitate migration (5). The most common complications reported so far after clip migration (obstructive jaundice, cholangitis, pancreatitis and biliary cholic) can be observed anytime between 11 days and 20 years after laparoscopic cholecystectomy (6).

Hostile environments such as schleroatrophic cholecystitis and biliary pancreatitis may increase even more the likelihood of poorly placed clips to migrate (7). Some studies reported that the use of absorbable clips seems to produce less complications when compared to titanium clips (8).

The peak of reported cases was between 1994 and 1998 in the early years of laparoscopic surgery for gallstone disease (6). It was advocated early on that intraoperative cholangiogram is safe and feasible for common bile duct exploration but this involves extensive dissection of the cystic duct $(9,10)$. If the surgeon decides for transcystic biliary drainage, ligature should be used to secure the catheter in place because clip placement may put the cystic stump at risk during tube extraction. Laparoscopic ultrasound might prove useful and less invasive for detecting bile duct stones without the need for exces- 
sive dissection of biliary structures (11).

The migrated clips act as a core to form gallstones by precipitation of amorphous and crystalline material (12). Most gallstones that form around migrated clips or suture material are brown, but may also be mixed containing cholesterol. The formation of brown stones is associated with infection and particularly Escherichia coli (12).

ERCP is considered to be the procedure of choice for retrieving common bile duct migrated clips, with a success rate of $84.5 \%$ (6). If for different reasons ERCP fails or can't be performed due to altered anatomy or previous gastrointestinal tract surgery, percutaneous transhepatic management may be attempted, otherwise surgical common bile duct exploration is warranted $(13,14)$.

Our opinion is that in the presented case, clip migration started once the transcystic catheter was removed. Being secured in place by 2 clips, after removal of the catheter, the cystic stump was left ineffectively closed but the sphincterotomy prevented bile leakage. The operative setting, after resolution of biliary pancreatitis and 2 ERCP attempts also acted as cofactors. But why the clip did not pass into the duodenum through a presumably wide papilla is difficult to understand.

\section{Conclusion}

In summary, clip migration is an unusual complication after laparoscopic cholecystectomy. This report illustrates the minimally invasive management of obstructive jaundice due to clip migration 9 years after laparoscopic cholecystectomy.

\section{Conflict of Interest}

The authors declare no conflicts of interests.

\section{References}

1. Raoul J, Bretagne J, Siproudhis L, Heresbach D, Campion J, Gosselin M. Cystic duct clip migration into the common bile duct: a complication of laparoscopic cholecystectomy treated by endoscopic biliary sphincterotomy. Gastrointestinal endoscopy. 1992;38(5):608-11.

2. Arnaud J-P, Bergamaschi R. Migration and slipping of metal clips after celioscopic cholecystectomy. Surgical laparoscopy \& endoscopy. 1993;3(6):487-8.

3. Kitamura K. Why do cystic duct clips migrate into the common bile duct? The Lancet. 1995;346:965-6.

4. Dolay K, Alis H, Soylu A, Altaca G, Aygun E. Migrated endoclip and stone formation after cholecystectomy: a new danger of acute pancreatitis. World Journal of Gastroenterology: WJG. 2007; 13(47):6446.

5. Deans GT, Wilson MS, Brough WA. The ability of laparoscopic clips to withstand high intraluminal pressure. Archives of Surgery. 1995;130(4):439-41.

6. Chong VH, Chong CF. Biliary complicati

ons secondary to post-cholecystectomy clip migration: a review of 69 cases. Journal of Gastrointestinal Surgery. 2010;14(4):688-96.

7. Calu V, Dumitrescu I, Miron A. The role of laparoscopy in the surgical treatment of scleroatrophic cholecystitis. Chirurgia (Bucur). 2010;105(5):653-6.

8. Bencini L, Boffi B, Farsi M, Sanchez LJ, Scatizzi M, Moretti R. Laparoscopic cholecystectomy: retrospective comparative evaluation of titanium versus absorbable clips. Journal of Laparoendoscopic \& Advanced Surgical Techniques. 2003; 13(2):93-8.

9. Cuschieri A, Shimi S, Banting S, Nathanson L, Pietrabissa A. Intraoperative cholangiography during laparoscopic cholecystectomy. Surgical endoscopy. 1994;8(4):302-5.

10. Giulea C, Enciu 0, Birca T, Miron A. Selective intraoperative cholangiography in laparoscopic cholecystectomy. Chirurgia (Bucur). 2016;111(1):26-32.

11. Cociorvei A, Calu V. Laparoscopic ultrasound in biliary diseases. Chirurgia (Bucharest, Romania: 1990). 2011;106(3):353-8.

12. Migration of Metallic Clips Used During Laparoscopic Cholecystectomy and Formation of Gallstones Around Them: Surgical Implications from a Prospective Study. Journal of Laparoendoscopic \& Advanced Surgical Techniques. 1997;7(1):37-46.

13. Williams EJ, Green J, Beckingham I, Parks R, Martin D, Lombard $M$. Guidelines on the management of common bile duct stones (CBDS). Gut. 2008;57(7):1004-21.

14. Ray S, Bhattacharya SP. Endoclip migration into the common bile duct with stone formation: a rare complication after laparoscopic cholecystectomy. JSLS: Journal of the Society of Laparoendoscopic Surgeons. 2013;17(2):330. 